\title{
Evaluation of silages of hybrids of napier grass and sorghum in the low country wet zone of Sri Lanka
}

\section{Bewertung von Silagen von Hybriden von Napiergrass und Sorghum in der Feuchtzone des Tieflands von Sri Lanka}

\author{
Thakshala Rupanjanie Seresinhe ${ }^{1}$, Piyatilak Bandara Weerasinghe ${ }^{2}$, Janith Sanjeewa ${ }^{1}$, Hansini Harindrika ${ }^{1}$, \\ Ariyathilaka Manawadu ${ }^{1}$, Kumara Mahipla ${ }^{3}$, Christine Iben $^{4}$
}

\footnotetext{
${ }^{1}$ Department of Animal Science, Faculty of Agriculture, University of Ruhuna, Matara-Kamburupitiya Rd, 81100 Mapalana, Sri Lanka

${ }^{2}$ Veterinary Research Institute, Gannoruwa, Peradeniya, Sri Lanka

${ }^{3}$ Department of Animal Science, Faculty of Agriculture, University of Peradeniya, Sri Lanka

${ }^{4}$ Institute of Animal Nutrition and Functional Plant Compounds, University of Veterinary Medicine Vienna, Veterinärplatz 1, 1210 Vienna, Austria

* Corresponding author: tseresinhe@gmail.com
}

Received: 21 August 2019, received in revised form: 9 January 2020, accepted: 13 January 2020

\section{Summary}

Silages of hybrids of napier grass (CO-3 or CO- 4 ) and sorghum and their combinations ( $50 \%$ napier grass hybrid $+50 \%$ of sorghum) were tested under three cutting intervals (4, 6 and 8 weeks). Sorghum silage had a leafy and soft texture with a fruity smell, which proved its desirable character with normal lactic acid fermentation. As such, it was with its comparatively higher dry matter content at the 6 or 8 weeks cutting interval, more suitable for ensiling. The crude protein concentration was not modified by the ensiling process, which was proved by the low ammoniacal nitrogen content. Sorghum silage had lower $\mathrm{pH}$ values at all three cutting intervals. On the basis of the $\mathrm{NH}_{3}-\mathrm{N} / \mathrm{TN}$ content $(<10 \%)$, all silages could be considered as of good quality. Sorghum silage could be considered as the best among tested silages as compared with hybrid napier var. CO-3 or CO-4. The optimum quality of the sorghum silage with the highest soluble carbohydrates concentration and lactic acid $>3 \%$ could be obtained at the 6 -week cutting interval.

Keywords: ammonia nitrogen, cutting interval, lactic acid, soluble carbohydrates

\section{Zusammenfassung}

Silagen von Hybriden von Napiergras (CO-3 oder CO-4) und Sorghum und deren Kombinationen (50 \% Napiergras-Hybrid + $50 \%$ Sorghum) wurden bei drei Schnittfrequenzen (4, 6 und 8 Wochen) getestet. Sorghumsilage hatte eine blättrige und weiche Textur mit einem fruchtigen Geruch, der seinen wünschenswerten Charakter bei normaler Milchsäuregärung bewies. Als solches war sie mit ihrem vergleichsweise höheren Trockensubstanzgehalt bei den 6- oder 8-wöchigen Schnittfrequenzen besser zum Silieren geeignet. Der Rohproteingehalt wurde durch den Silierprozess nicht verändert, was durch den niedrigen Gehalt an Ammoniumstickstoff belegt wurde. Sorghumsilage hatte bei allen drei Schnittfrequenzen niedrigere $\mathrm{pH}-$ Werte. Bezogen auf den $\mathrm{NH}_{3}-\mathrm{N} / \mathrm{TN}-\mathrm{Gehalt}(<10 \%)$ können alle Silagen als von guter Qualität angesehen werden. Sorghumsilage kann als die beste unter den getesteten Silagen im Vergleich zu HybridNapiersorten angesehen werden. Die optimale Qualität der Sorghumsilage mit der höchsten Konzentration an löslichen Kohlenhydraten und Milchsäure >3 \% konnte bei einer Schnittfrequenz von 6 Wochen erzielt werden.

Schlagworte: Ammoniakstickstoff, Schnittfrequenz, Milchsäure, lösliche Kohlenhydrate 


\section{Introduction}

The dairy industry has a potential to contribute considerably to Sri Lanka's economic development. A traditional industry surviving thousands of years, milk production also plays an important role in alleviating nutritional poverty in all age groups. At present, Sri Lanka has self-sufficiency with its milk products of approximately $40 \%$ and it is needed to import about $60 \%$ of milk products to fulfill the domestic requirements. Cattle and buffalo population in the country in 2018 has been recorded as 1.46 million and 0.46 million, respectively. Domestic milk production was recorded as 494.85 million liters and import of dairy products amounted to $104,861.87$ mega tonnes in 2018 (DAPH, 2018).

The country has a great potential to improve dairy farming as a commercially viable rural enterprise, providing an opportunity for farmers to increase their income and build assets to improve their livelihoods. However, this can only be achieved by ensuring a year-round good quality feed supply in the country. The main feed resources for ruminants in Sri Lanka are natural pasture and crop residues, which are low in quality and quantity for sustainable livestock production (Ibrahim et al., 1999). However, in many developing countries, because of the ever-growing need for food for humans, only limited cultivated land can be allocated to produce fodder for livestock. One of the solutions to overcome the seasonal fodder deficiency is the conservation of surplus fodder during peak fodder growth period. Silage production is not a common practice among livestock farmers generally in the tropical countries but it 'is becoming popular at recent times to bridge the dry season gap. In 2013, the government introduced a dairy project to promote medium- and large-scale dairy farms that have the state-of-the-art technology, allowing them to achieve the maximum potential from dairy cows. Therefore, production of silage becomes an essential need in the country. There are different kinds of crops used for silage making. Crops that provide adequate levels of moisture, soluble carbohydrates (SCHO), and other nutrients (Cullison, 1975) are facilitating to prepare good quality silage for ruminant feeding. Forage crops such as hybrid napier (Pennisetum purpureum Schumach $\times$ Pennisetum americarnum) varieties CO-3 and CO-4 (P. purpureum Schumach $\times$ Pennisetum glaucum) have recently become popular and are grown by the farmers in various locations. Both varieties are characterized by its profuse tillering ability, high-yield potential, high crude protein $(\mathrm{CP})$ concentration, quick re-growth capacity, high palatability, free from other adverse factors, and resistance to pest and disease attacks (Premaratne and Premalal, 2006; Pavan et al., 2015). Sorghum bicolor (L.) Moench is grown as an important forage crop in dairy farms of Sri Lanka, to bridge the dry season that lasts from October to January (Houwers et al., 2015).

Three fodder varieties, namely, hybrid napier var. CO-3 and CO-4 and sorghum var. Sugar graze, were introduced to low country wet zone of Sri Lanka recently, to use as potential animal fodder. As a further step, experiment was conducted to investigate the effect of cutting interval $(4,6$, and 8 weeks) on the quality of silages prepared from above three forages while assessing the physical and chemical composition of prepared silages. In Sri Lanka, silage production in general is limited among smallholders. Therefore, this study was conducted to popularize silage making in small bags as a low-cost alternative suitable for resourcepoor smallholders to alleviate dry-season feed constraints. Bag silage allows conservation of fodder in small quantities for a long period, in contrast to traditional silage making where large amounts of fodder must be harvested and chopped at one time. Thus, small holder farmers can conserve two or three bags a day over the whole growing season. It also involves low investment cost and low risk and is also practical when no access to machinery, for example, tractors, forage harvesters, and bailors, is available. This method is already adopted in Pakistan and Nepal (Lane, 2006) and in Honduras (Reiber et al., 2009) and becoming a viable practice on both commercial and small-scale farms in Sri Lanka, whereas silage production in plastic barrels or vacuum-packed polythene bags are common (Weerasinghe, 2019).

\section{Materials and methods}

\subsection{Experimental location}

The field experiment was conducted in the Faculty of Agriculture research farm, University of Ruhuna, Mapalana, Kamburupitiya, Sri Lanka, started from February 2017 (low country wet zone, $58 \mathrm{~m}$ above mean sea level, latitude and longitude: $7.8731^{\circ} \mathrm{N}, 80.7718^{\circ} \mathrm{E}$, mean annual rain fall: $2,400 \mathrm{~mm}$, and mean annual temperature: $\left.27-31^{\circ} \mathrm{C}\right)$. The experimental site was cropped with Calliandra (Calliandra calothyrsus) for 3 years before the establishment of the present experimental plots. The site was ploughed with a mold board plough and har- 
rowed and leveled with a tine tiller. The soil type was redyellow podzolic. Soil samples were randomly collected from the experimental location before planting and analyzed for physiochemical properties $(\mathrm{pH}=5.8$, bulk density $=0.8 \mathrm{~g} / \mathrm{cm}^{3}$, soil texture: sandy clay loam) using standard methods (Dharmakeerthi et al., 2007). The basal fertilizer application was given at planting and consisted of urea $(200 \mathrm{~kg} / \mathrm{ha})$, triple super phosphate $(120 \mathrm{~kg} / \mathrm{ha})$, and muriate of potash $(100 \mathrm{~kg} / \mathrm{ha})$.

\subsection{Experimental design}

The experimental design was a factorial arrangement in a randomized complete block design having three forages (hybrid napier var. CO-3, and var. CO-4 and, sorghum), three cutting intervals (4, 6, and 8 weeks), and three blocks. The plot size was $5 \mathrm{~m} \times 5 \mathrm{~m}$. A total of 27 plots were used. Two stem cuttings of hybrid napier grasses having two nodes were planted with $1 \mathrm{~m} \times 1 \mathrm{~m}$ spacing in one spot on February 14, 2017. An equalizer cut was performed for hybrid napier grasses at a standardized height of $5 \mathrm{~cm}$ after 3 months of planting (May 14, 2017). Sorghum seeds were planted on the date of equalizer cut was taken. Three seeds of sorghum were planted manually in one spot with $45 \mathrm{~cm} \times 15 \mathrm{~cm}$ spacing. After germination, two healthy seedlings were selected from each spot and other seedlings were thinned out. All plots were irrigated when required to ensure adequate soil moisture for plant growth. Weeds were slashed after 1 month of establishment.

\subsection{Preparation of silage}

All three forages were harvested at three cutting intervals of 4 (June 12, 2017), 6 (June 26, 2017), or 8 weeks (July 10, $2017)$ at $7.5 \mathrm{~cm}$ height above ground level. Initially, guard rows were discarded. Subsequently, the net plots were harvested and fresh weights were recorded. Neither wilting practice nor additives were used in any of the silage type. The silage types were as follows:

- Hybrid napier var. CO-3 (100\%)

- Hybrid napier var. CO-4 (100\%)

- Sorghum var. sugar graze $(100 \%)$

- Hybrid napier var. CO-3 (50\%) + Sorghum (50\%)

- Hybrid napier var. CO-4 (50\%) + Sorghum (50\%)

\subsection{Preparation of laboratory silos}

Strong high-density black polythene bags to hold $5 \mathrm{~kg}$ (laboratory silo) were used as fermenting unit. The quantity used for silages depended on the fresh matter yield of different forages (Table 1) as well as based on the fact that one cow should be fed one bag a day in addition to existing feeds as a green fodder supplement. All bags were carefully packed with forage without making any holes $(5 \mathrm{~kg}$ fresh matter, chopped at 1-2 cm length) gently but firmly squeezed the bag by hand to expel air, vacuumed, sealed, and stored in a dark room for 6 weeks at room temperature (around $30^{\circ} \mathrm{C}$ ). Silage samples were prepared at subsequent harvest as well in the same manner. In addition to the silages prepared from

Table 1. Fresh matter yields of silages

Tabelle 1. Frischmasseerträge der Silagen

\begin{tabular}{|c|c|c|c|c|c|c|}
\hline \multirow[t]{2}{*}{ Harvest } & \multirow{2}{*}{$\begin{array}{l}\text { Harvesting interval } \\
\text { (weeks) }\end{array}$} & \multicolumn{3}{|c|}{ Fresh matter yield (t/ha/cut) } & \multicolumn{2}{|c|}{$\mathrm{p}$-Value } \\
\hline & & $\mathrm{HN}$ var. $\mathrm{CO}-3$ & $\mathrm{HN}$ var. $\mathrm{CO}-4$ & Sorghum & & \\
\hline \multirow[t]{3}{*}{1} & 4 & $12.70 \pm 0.26 \mathrm{~d}$ & $10.44 \pm 0.23 \mathrm{~d}$ & $5.74 \pm 0.22 \mathrm{e}$ & $\mathrm{V}$ & 0.000 \\
\hline & 6 & $29.04 \pm 0.52 b$ & $22.70 \pm 0.39 c$ & $28.41 \pm 1.10 \mathrm{~b}$ & $\mathrm{H}$ & 0.000 \\
\hline & 8 & $40.93 \pm 0.49 \mathrm{a}$ & $37.56 \pm 0.84 \mathrm{a}$ & $38.33 \pm 2.17 \mathrm{a}$ & $\mathrm{V} \times \mathrm{H}$ & 0.000 \\
\hline \multirow[t]{3}{*}{2} & 4 & $9.81 \pm 0.92 \mathrm{~d}$ & $9.63 \pm 1.95 \mathrm{~d}$ & $5.94 \pm 0.34 \mathrm{e}$ & $\mathrm{V}$ & 0.000 \\
\hline & 6 & $30.85 \pm 0.87 b$ & $23.15 \pm 0.18 \mathrm{c}$ & $30.17 \pm 1.12 \mathrm{~b}$ & $\mathrm{H}$ & 0.000 \\
\hline & 8 & $42.93 \pm 0.35 a$ & $38.48 \pm 0.91 \mathrm{a}$ & $39.37 \pm 1.53 \mathrm{a}$ & $\mathrm{V} \times \mathrm{H}$ & 0.000 \\
\hline
\end{tabular}

Means of main factors and interactions with similar superscripts in rows and columns for different harvests are not significantly different at $(\mathrm{p}>0.05)$. HN $=$ hybrid napier, $\mathrm{V}=$ variety, $\mathrm{H}=$ harvesting interval. 
three main crops, Napier CO-3, Napier Co-4, and fodder sorghum, two combinations of silages were also prepared. Forage materials were taken from the same harvests in a same manner to prepare the additional two mixed silage types without deviating from the experimental design. There were 5 silage types $\times 3$ cutting intervals $\times 2$ harvests $\times 3$ replicates $=90$ samples. Following observations were performed after opening the silos: physical parameters such as texture, color, aroma, and molds present or not were determined by following the silage note prepared by New South Wales Dept. of Primary Industries (2008). The dry matter (DM) content of silages was determined according to Association of Analytical Chemists (1980). Chemical parameters such as pH (AFIA, 2011), lactic acid (Bernett, 1951), ammonia nitrogen (Zaklouta, 2011), and SCHO (AFIA, 2011) were determined immediately after opening of laboratory silos.

\subsection{Statistical analyses}

The General Linear Models procedure was used to compare the mean differences between five silage types and three cutting intervals. Duncan's multiple range test was used to test the differences between means. Differences between means were considered significant if p-values were less than 0.05 . The data set was analyzed using SAS University Edition.

\section{Results and Discussion}

\subsection{Effect of silage type and cutting interval on physical characteristics of silage}

It was observed that both grass silages (hybrid napier var. $\mathrm{CO}-3$ and hybrid napier var. CO-4) had wet and leafy texture, which was more typical for tropical grasses. Both grass silages have olive green color, falling within the normal color range for grass silages. Both had little fruity smell, which may be associated with lower fermentation especially from crops with low sugar content. Sorghum silage had a leafy and soft texture likely to be associated with higher digestibility. The silage falls into the normal color range, whereas mild, high fruity smell proved its desirable character with normal lactic acid fermentation. Both mixed silages (hybrid napier var. CO-3 (50\%) + sorghum (50\%), hybrid napier var. CO-4 (50\%) + sorghum $(50 \%)$ have soft but medium wet appearance. It is pale to light green color fallen within the normal color range for grass and cereal silages. Both had medium fruity smell, which may be associated with fermentation especially from crops with medium sugar content. All silages prepared were free from molds (Table 2).

\subsection{Effect of silage type and cutting interval on quality characteristics}

The sorghum var. Sugar graze silages had a higher DM content when compared with the silages of hybrid napier var. CO-3 or var. CO-4 mixtures with $50 \%$ sorghum (Table 3). Silage made from hybrid napier var. CO-3 exhibited the lowest DM concentration among all silages tested. Generally, the DM content of all silages was lower than that of expected values. Bandara et al. (2016) reported DM percentage of 24.1 and 22.1, respectively, for hybrid napier var. CO-3 and sorghum var. Sugar graze.

Furthermore, the DM contents of hybrid napier var. $\mathrm{CO}-3$ or var. CO-4 silages were lower in the current study at 8 -week cutting intervals ( 56 days after regrowth) when compared with the values of dos Santos et al. (2013) for silages prepared with dwarf elephant grass clones. They indicated that dwarf clones are more likely to become

Table 2. Effect of silage types on physical characteristics of silage

Tabelle 2. Einfluss der Silagetypen auf die physikalischen Eigenschaften der Silage

\begin{tabular}{|c|c|c|c|c|c|}
\hline \multirow[t]{2}{*}{ Parameters } & \multicolumn{5}{|c|}{ Silage type } \\
\hline & $\mathrm{HN}$ var. $\mathrm{CO}-3$ & $\mathrm{HN}$ var. $\mathrm{CO}-4$ & Sorghum & $\begin{array}{c}\text { HN var. CO-3 }(50 \%)+ \\
\text { Sorghum }(50 \%)\end{array}$ & $\begin{array}{c}\text { HN var. CO-4 }(50 \%)+ \\
\quad \text { Sorghum }(50 \%)\end{array}$ \\
\hline $\begin{array}{c}\text { Physical appearance } \& \\
\text { texture }\end{array}$ & Wet and leafy & Wet and leafy & Leafy, soft texture & Soft, medium wet & Soft, medium wet \\
\hline Color & Olive green & Olive green & Light green to green & Pale green to light green & Pale green to light green \\
\hline Aroma & Little fruity smell & Little fruity smell & Mild, high fruity smell & Medium fruity smell & Medium fruity smell \\
\hline Molds & Absent & Absent & Absent & Absent & Absent \\
\hline
\end{tabular}

$\mathrm{HN}$ = hybrid napier. Only the type was considered; the frequency was not considered. 


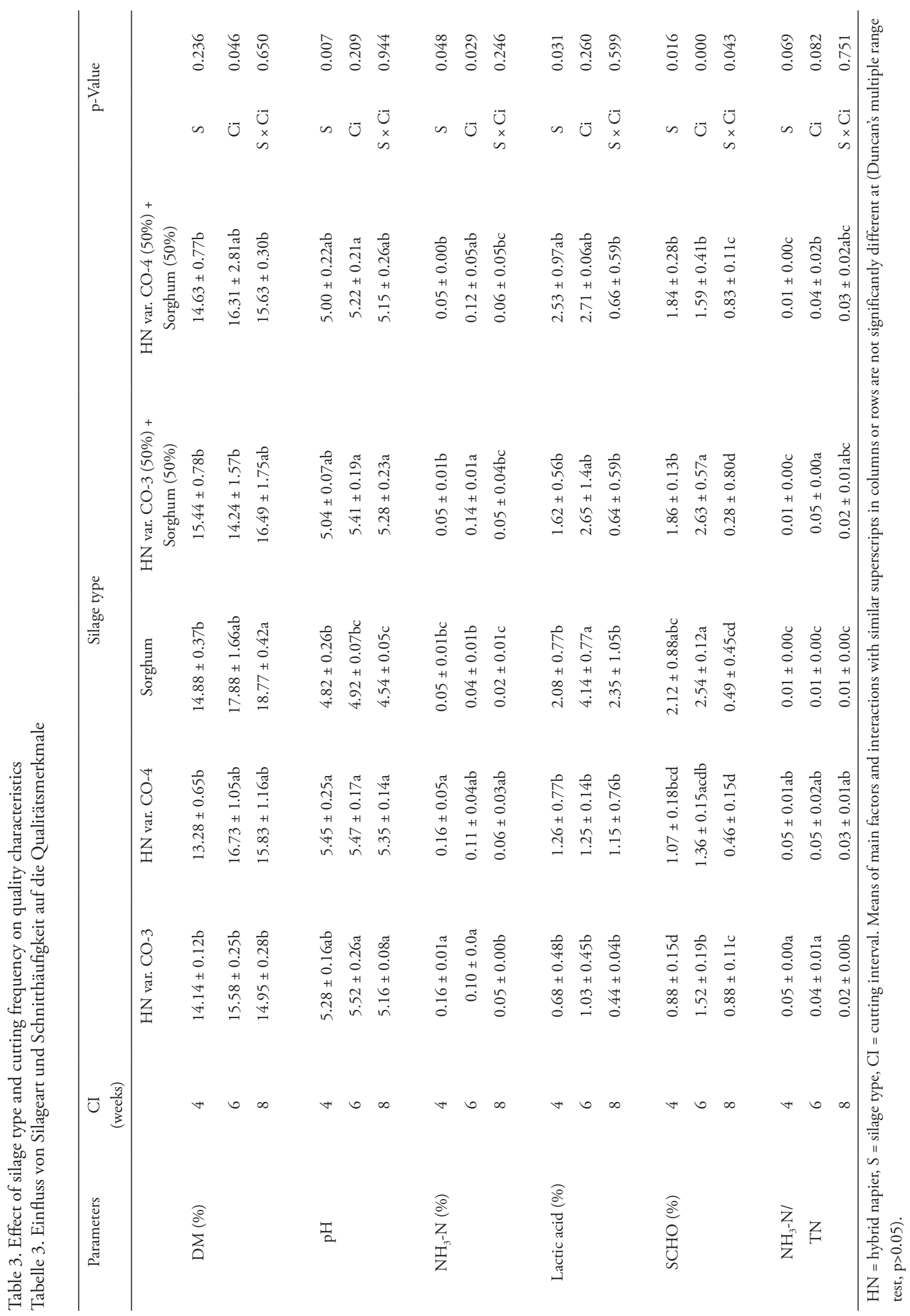


dehydrated after cutting when compared with tall elephant grass varieties. Therefore, it could be suggested that, the lower DM contents of hybrid napier var. CO-3 and hybrid napier var. CO-4 silages could have been partly due to no wilting and no addition of additives as well as due to prevailed rainy conditions during the whole experimental period. Furthermore, hybrid napier var. $\mathrm{CO}-3$ and var. $\mathrm{CO}-4$ and sorghum were introduced newly to the low country wet zone of Sri Lanka and the plants were only 4-5 months old when harvested for silages. Therefore, it can be suggested that the performance of all three varieties was suboptimal when compared with other studies conducted with same species.

When considering the cutting intervals, all silages produced significantly higher DM with longer cutting interval. Forages with greater potential for ensiling must have an adequate DM for fermentation. Therefore, sorghum with high DM concentration at 6 or 8 cutting intervals are more suitable for ensiling when compared with hybrid napier var. CO-3 or hybrid napier var. CO-4. McDonald (1981) reported that plant cells were broken down and plant juices (SCHO) were released by plasmolysis, which was a pre-requisite for the development of lactic acid bacteria during the early stages of ensilage.

Silages prepared with sorghum revealed satisfactory $\mathrm{pH}$ values at all cutting intervals (Table 3) when compared with mixtures and two grass silages. In this study, all the silages had $\mathrm{pH}$ greater than 4 and could be classified as fairly good. Thus, the obtained $\mathrm{pH}$ values indicated that all silage types did not have sufficient availability of SCHO for adequate fermentation. However, $\mathrm{pH}$ cannot be used as a sole fermentative indicator, because other factors, such as the ammoniacal nitrogen, lactic acid, butyric acid, and homo/hetero fermentation characteristics, are important to measure fermentation quality; indeed these variables should be used as indicators to measure fermentation quality (Jobim et al., 2007; dos Santos et al., 2013)

The respective ammoniacal nitrogen $\left(\mathrm{NH}_{3}-\mathrm{N} / \mathrm{TN}\right)$, lactic acid content, and water-soluble $\mathrm{CHO}$ content decreased as the cutting interval increased from 4 to 8 weeks. In relation to $\mathrm{NH}_{3}-\mathrm{N} / \mathrm{TN}$ content, all silages can be considered as of good quality, because all the values were below $10 \%$ (Table 3). Ammoniacal $\mathrm{N}$ is a product of clostridial fermentations, and the ammonia content must be less than or equal $12 \%$ of the total nitrogen $(\mathrm{TN})$ for grass $(\mathrm{McD}$ onald et al., 1991).

Highest lactic acid content was observed in all silage samples at 6-week cutting interval with a maximum of
$4.14 \% \pm 0.77 \%$ for sorghum silage. Having higher percentage of lactic acid ( $>3 \%)$ is a good indicator of quality silage, and sorghum silage could be considered as the best among tested silages. Lactic acid concentration of all silages decreased with advancement of maturity of all fodders. However, Bandara et al. (2016) reported that the lactic acid content of sorghum at $50 \%$ flower initiation stage was higher $5.90 \% \pm 0.46 \%$ when compared with the value obtained in the current study.

Highest $\mathrm{SCHO}$ was observed in all silage samples at 6-week cutting interval with a maximum of $2.63 \% \pm 0.57 \%$ for sorghum. SCHO concentration of all silages decreased with the advancement of maturity of all fodders, whereas fiber content of the grasses increased with maturity. Bandara et al (2016) reported that the SCHO content of sorghum at $50 \%$ flower initiation stage, which was comparable with the values in the current study.

\subsection{Effect of silage type and cutting interval on nutrient concentration}

Lowest ash content was observed for hybrid napier var. CO-4 silage, whereas sorghum silage had the highest ash content at 4-week cutting interval. Ash content of all the silages was decreased when the cutting interval increased (Table 4). More or less similar values were reported by Santos et al. (2012) for elephant grass varieties.

Although not significant, all silages had highest CP content under 4-week cutting interval and decreased toward increasing cutting intervals (Table 4). The CP content of sorghum silage at cutting intervals of 6 and 8 weeks was higher when compared with the silage of both hybrids of napier grass with the mixed silages showing intermediate values. Furthermore, the values were similar to those that have been previously reported in the literature for elephant grass silage (Pinho et al., 2008). All silages contained more than $7 \%$ CP to provide sufficient nitrogen for effective microbial fermentation in the rumen (Church, 1988). The percentage of CP was not modified with the ensiling process. That could be proved by the low ammoniacal nitrogen content of all silages.

The lowest crude fiber content was observed for sorghum silage, whereas the highest values were observed for hybrid napier var. CO-3 and CO-4 silages. Crude fiber content was clearly increased in all silages when the cutting interval was increased (Table 4). The crude fiber values reported by Bandara et al. (2014) were far higher than those observed in the present study for hybrid napier and sorghum. 
Table 4. Effect of silage type and cutting frequency on nutrient concentration

Tabelle 4. Einfluss von Silagetyp und Schnitthäufigkeit auf die Nährstoffkonzentration

\begin{tabular}{|c|c|c|c|c|c|c|c|c|}
\hline \multirow[t]{2}{*}{ Parameters } & \multirow{2}{*}{$\begin{array}{c}\text { CI } \\
\text { (weeks) }\end{array}$} & \multicolumn{5}{|c|}{ Silage type } & & \multirow[t]{2}{*}{ p-Value } \\
\hline & & $\mathrm{HN}$ var. $\mathrm{CO}-3$ & $\mathrm{HN}$ var. CO-4 & Sorghum & $\begin{array}{c}\mathrm{HN} \text { var. CO-3 }(50 \%)+ \\
\text { Sorghum }(50 \%)\end{array}$ & $\begin{array}{c}\mathrm{HN} \text { var. CO-4 }(50 \%)+ \\
\text { Sorghum }(50 \%)\end{array}$ & & \\
\hline \multirow[t]{3}{*}{ Ash (\%) } & 4 & $12.44 \pm 0.05 b$ & $9.26 \pm 0.06 \mathrm{~d}$ & $12.78 \pm 0.05 \mathrm{a}$ & $12.61 \pm 0.04 \mathrm{ab}$ & $11.02 \pm 0.49 \mathrm{c}$ & S & 0.000 \\
\hline & 6 & $8.32 \pm 0.04 \mathrm{fg}$ & $7.64 \pm 0.05 \mathrm{~h}$ & $8.68 \pm 0.05 e$ & $8.50 \pm 0.03 \mathrm{ef}$ & $8.16 \pm 0.05 \mathrm{~g}$ & $\mathrm{Ci}$ & 0.000 \\
\hline & 8 & $7.61 \pm 0.07 \mathrm{~h}$ & $7.13 \pm 0.06 \mathrm{i}$ & $6.81 \pm 0.04 j$ & $7.21 \pm 0.05 \mathrm{i}$ & $6.97 \pm 0.04 \mathrm{ij}$ & $\mathrm{S} \times \mathrm{Ci}$ & 0.000 \\
\hline Crude & 4 & $20.96 \pm 0.12 \mathrm{a}$ & $20.73 \pm 0.2 \mathrm{ab}$ & $20.52 \pm 0.05 b$ & $20.74 \pm 0.05 \mathrm{ab}$ & $20.62 \pm 0.08 b$ & S & 0.000 \\
\hline \multirow[t]{2}{*}{ Protein (\%) } & 6 & $14.41 \pm 0.08 \mathrm{e}$ & $14.66 \pm 0.47 \mathrm{e}$ & $18.88 \pm 0.10 c$ & $16.65 \pm 0.02 \mathrm{~d}$ & $16.77 \pm 0.04 \mathrm{~d}$ & $\mathrm{Ci}$ & 0.000 \\
\hline & 8 & $13.63 \pm 0.05 \mathrm{~g}$ & $13.66 \pm 0.27 \mathrm{~g}$ & $14.50 \pm 0.07 \mathrm{e}$ & $14.06 \pm 0.06 f$ & $14.08 \pm 0.06 f$ & $\mathrm{~S} \times \mathrm{Ci}$ & 0.000 \\
\hline Crude & 4 & $27.16 \pm 0.17 \mathrm{a}$ & $27.38 \pm 0.15 \mathrm{de}$ & $21.88 \pm 0.13 \mathrm{~g}$ & $24.52 \pm 0.29 f$ & $24.63 \pm 0.34 f$ & $S$ & 0.000 \\
\hline \multirow[t]{2}{*}{ Fiber (\%) } & 6 & $29.02 \pm 0.39 c$ & $29.04 \pm 0.16 \mathrm{c}$ & $26.57 \pm 0.13 \mathrm{e}$ & $27.79 \pm 0.58 \mathrm{~d}$ & $27.80 \pm 0.37 d$ & $\mathrm{Ci}$ & 0.000 \\
\hline & 8 & $30.02 \pm 0.18 b$ & $31.48 \pm 0.10 \mathrm{a}$ & $28.71 \pm 0.15 c$ & $29.37 \pm 0.45 b c$ & $30.10 \pm 0.36 b$ & $\mathrm{~S} \times \mathrm{Ci}$ & 0.000 \\
\hline
\end{tabular}

$\mathrm{HN}=$ hybrid napier, $\mathrm{S}=$ silage type, $\mathrm{CI}=$ cutting interval. Means of main factors and interactions with similar superscripts in columns or rows are not significantly different at (Duncan's multiple range test, $\mathrm{p}>0.05$ ).

\section{Conclusions}

On the basis of the assessment of physical, nutritional, and chemical quality of silages, sorghum was promising for silage production as compared with hybrid napier var. CO-3 or CO-4. To get the optimum quality, the sorghum crop should be harvested at 6 -week interval. It could be suggested that sorghum could be effectively used as silage to improve the nutritional status of dairy cows in Sri Lanka.

\section{Acknowledgment}

Authors are gratefully acknowledge the financial assistance (research grant-RG/2017/AG/04) of the National Science Foundation of Sri Lanka.

\section{References}

AFIA (2011): Laboratory methods manual. A reference manual of standard methods for the analysis of fodder. Version 7, Australian Fodder Industry Association Limited, pp. 80-81.

AOAC (1980): Official Methods of Analysis. Association of Official analytical Chemists, Washington, DC, USA.
Bandara, P.G.G., Premalal, G.G.C. and W.A.D. Nayananjalie (2016): Comparison of yield, nutritive value and silage quality of fodder sorghum (Sorghum bicolor) and maize (Zea mays) with hybrid napier variety CO-3. Rajarata University Journal 4, 26-31.

Bernett, A.J.G. (1951): The colorimetric determination of lactic acid in silage. Biochemical Journal 49, 527-529.

Church, D.C. (1988): The ruminant animal digestive physiology and nutrition. Prentice Hall, New Jersey, NJ, USA.

Cullison, A.E. (1975): Feeds and Feeding. Reston Publishing Co., Reston, Virginia, USA.

DAPH (2018): Annual Report. Department of Animal Production \& Health, Sri Lanka.

Dharmakeerthi, R.S., Indraratne, S.P. and D. Kumaragamage (2007): Manual of soil sampling and analysis. Soil Science Society of Sri Lanka, Peradeniya, Sri Lanka, pp. 10-20.

Dos Santos, R.J.C., Lira, M.A., Guim, A., dos Santos, M.V.F., Dubeux Jr., J.C.B. and A.C.L. de Mello (2013): Elephant grass clones for silage production. Scientia Agricola 70, 6-11.

Houwers, W., Wouters, B. and A. Vernooij (2015): Sri Lanka fodder study; An overview of potential, bottlenecks and improvements to meet the rising demand for quality fodder in Sri Lanka. Livestock Research Report 924, Wageningen University, The Netherlands. 
Ibrahim, M.N.M., Staal, S.J., Daniel, S.L.A. and W. Thorpe (1999): Appraisal of the Sri Lanka dairy sector. Volume 1: Main Report. Ministry of Livestock Development and Estate Infrastructure, Sri Lanka, 97 pp.

Jobim, C.C., Nussio, L.G., Reis, R.A. and P. Schmidt (2007): Methodological advances in evaluation of preserved forage quality. Revista Brasileira de Zootecnia 36, 101-119.

Kumar, P.P., Venkateswarlu, M., Raghunandan, R., Sudheer Babu, A. and R.P. Kumar (2015): Utilization of CO-4 variety of hybrid napier (napier $\times$ pearl millet) fodder supplemented with energy and protein in sheep. Indian Journal of Animal Nutrition 32, 439-444.

Lane, I.R (2000): Little bag silage. In: 't Mannetje, T. (Ed.): Silage making in the tropics with particular emphasis on small holders. Proceedings of the FAO Electronic Conference on Tropical Silage, FAO Plant Production and Protection Paper 161, Rome, Italy, pp. 79-83.

McDonald, P. (1981): The biochemistry of silage. J. Wiley, Chichester, England, 226 pp.

McDonald, P., Henderson, A.R. and S.J.E. Heron (1991): The Biochemistry of Silage. Chalcombe Publications, Marlow, UK, 340 pp.

NSW DPI (2008): Field assessment of silage. New South Wales, Department of Primary Industries. https://www. dpi.nsw.gov.au/agriculture/pastures-and-rangelands/ silage. Accessed on 8 July 2019.
Pinho, B.D., Pires, A.J.V., Ribeiro, L.S.O. and G.G.P. Carvalho (2008): Elephant Grass silage with cassava meal. Revista Brasileira de Saúde e Produção Animal 9, 641-651.

Premaratne, S. and G.G.C. Premalal (2006): Hybrid napier (Pennisetum perpureum $x$ Pennisetum americarnum) var. CO-3: A resourceful fodder grass for dairy development in Sri Lanka. The Journal of Agricultural Sciences 2, 22-33.

Reiber, C., Schutze-Kraft, R., Peters, M. and V. Hoffmann (2009): Potential and constraints of little bag silage for small holders - Results and experience from Honduras. Experimental Agriculture 45, 209-220.

Weerasinghe, W.M.P.B. (2019): Livestock feeds and feeding practices in Sri Lanka. In: Samanta, K., Bokhtiar, S.M. and M.Y. Ali (Eds.): Livestock feeding and feeding practices in South Asia. SAARC Agriculture Center, Dhaka, Bangladesh, pp. 181-206.

Vijayakumar, G., Babu, C., Velayudham, K. and T.S. Raveendran (2009): A high yielding cumbu napier hybrid grass $\mathrm{CO}(\mathrm{CN}) 4$. Madras Agricultural Journal 96, 291-292.

Zaklouta, M., Hilali, M., Nefzaoui, A. and M. Haylani (2011): Animal nutrition and product quality laboratory manual. International Center for Agricultural Research in the Dry Areas (ICARDA), Aleppo, Syria, 92 pp. 